\title{
Threatened fishes of the world: Chasmistes liorus Jordan, 1878 (Catostomidae)
}

\author{
Mike Whitney \\ Brigham Young University - Provo \\ Mark C. Belk \\ Brigham Young University - Provo, mark_belk@byu.edu
}

Follow this and additional works at: https://scholarsarchive.byu.edu/facpub

Part of the Biology Commons

\section{Original Publication Citation}

Michael Whitney, and Mark C. Belk. 2000. Threatened fishes of the world: Chasmistes liorus Jordan, 1878 (Catostomidae). Environmental Biology of Fishes 57: 362.

\section{BYU ScholarsArchive Citation}

Whitney, Mike and Belk, Mark C., "Threatened fishes of the world: Chasmistes liorus Jordan, 1878 (Catostomidae)" (2000). Faculty Publications. 5498.

https://scholarsarchive.byu.edu/facpub/5498 
See discussions, stats, and author profiles for this publication at: https://www.researchgate.net/publication/227214667

Threatened Fishes of the World: Chasmistes liorus Jordan, 1878 (Catostomidae)

Article in Environmental Biology of Fishes · April 2000

DOI: 10.1023/A:1007682911836

CITATIONS

18

2 authors, including:

Mark C. Belk

Brigham Young University - Provo Main Campus

143 PUBLICATIONS 2,776 CITATIONS

SEE PROFILE

Some of the authors of this publication are also working on these related projects:

Project Phylogeography and landscape genetics of aquatic fauna in Patagonia View project

Project Least Chub Demography View project 


\title{
Threatened fishes of the world: Chasmistes liorus Jordan, 1878 (Catostomidae)
}

\author{
Mike Whitney \& Mark C. Belk \\ Department of Zoology, Bringham Young University, Provo, UT 84604, U.S.A. (e-mail: mw33@netscape.net)
}

Common name: June sucker. Conservation status: Chasmistes liorus was listed as endangered by U.S. Fish and Wildlife Service on 31 March 1986 (U.S Fish and Wildlife 1986). Identification: Chasmistes liorus is one of four living species of lake suckers that comprise the genus Chasmistes (Jordan 1878). They can attain lengths of more than $600 \mathrm{~mm}$, and have 55 to 64 scales on the lateral line. They have a subterminal mouth. The upper lip is covered with small, irregularly developed papillae, while the lower lip has a deep cleft and the two lobes are widely separated (USNM 75832; Miller \& Smith 1981). Chasmistes liorus is distinguishable from other members of the genus by scale counts and location. Drawing by Mark C. Belk. Distribution: Chasmistes liorus is endemic

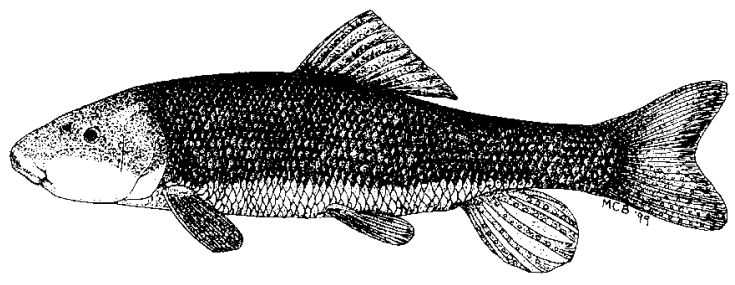
to Utah Lake and the lower Provo River, Utah Co., Utah, U.S.A. Historically, it may have spawned in other smaller tributaries of Utah Lake. Since 1989, eggs and sperm have been collected annually from spawning adults to provide juveniles for reintroduction and establishment of refuge populations. Captive and refuge populations currently include Red Butte Reservoir, Utah; the Millville Pond complex near Lehi, Utah; the Fisheries Experimental Station, in Logan, Cache Co., Utah; and Camp Creek Reservoir, Box Elder Co., Utah. Abundance: It is estimated that there are fewer than one thousand adults remaining in Utah Lake (Modde \& Muirhead 1994). Although embryos and larvae have been collected in the lower Provo River after spawning, few juveniles have been found despite numerous sampling efforts. Adult C. liorus in Red Butte Reservoir number in the hundreds. In 1998 they apparently reproduced in the reservoir, and about three thousand larvae were observed. Millville Pond complex may hold as many as 514 individuals. The Fisheries Fxperimental Station has approximately one thousand five-hundred individuals. At least 120 individuals are alive in Camp Creek Reservoir (K.W. Wilson unpublished data from surveys conducted in 1997). Habitat and ecology: Adult $C$. liorus are pelagic, feeding on aquatic invertebrates in the mid-water column and avoiding vegetated areas (Modde \& Muirhead 1994). However, juveniles inhabit emergent vegetation, apparently as a refuge from predators. As is typical of other lake suckers, C. liorus are long-lived and ages of more than forty years at death have been reported (Scoppettone 1988, Belk 1998). Historically, the large-bodied strain of cutthroat trout, Salmo clarki, native to Utah Lake was probably the most important predator of juveniles (Heckmann et al. 1981). Adults probably had few predators other than man and bears, which captured and consumed individuals as they moved up the Provo River to spawn. Cutthroat trout have been extirpated from Utah Lake. Currently, introduced white bass Morone chrysops, walleye Stizostedion vitreum, yellow perch Perca fluviatilis, largemouth bass Micropterus salmoides, green sunfish Lepomis cyanellus, bluegill Lepomis macrochirus, black bullhead Ictalurus melas, channel catfish Ictalurus punctatus, and carp Cyprinus carpio all occur in Utah Lake in large numbers and may be significant predators on larva and juvenile $C$. liorus. Reproduction: During the months of April and May, adults begin to congregate near the mouth of the Provo River. They spawn over gravel substrates in the lower $6 \mathrm{~km}$ of the Provo River from late May to mid-June. The timing of spawning appears to be influenced by water flow and temperature (Modde \& Muirhead 1994). Spawning appears to coincide with the decreasing leg of high spring flows. Embryos hatch within a few days, depending on temperature (Shirley 1983). Chasmistes liorus may reach maturity as early as five years of age and as late as ten (Belk 1998). Total length at maturity ranges from about 440 to $490 \mathrm{~mm}$ (Shirley 1983). Threats: From the 1850s to the 1940s the major threat to this species was the dewatering of the main stem of the Provo River and commercial fishing in Utah Lake. Dewatering of the Provo River in June during the drought of the early 1930s resulted in massive mortality of spawning adults (Miller \& Smith 1981). Minimum instream flows in the Provo River are now guaranteed and commercial fishing is no longer a threat. Current threats include predation on embryos, larvae and juveniles from introduced fish species and lack of suitable habitat for early development in the lower Provo river. Conservation action: Recovery efforts have focused on three areas. First, refuge stocks have been established. Second, fish weirs in the Provo River during the spawning season to restrict predators from entering the river and allow easier capture of spawning June suckers were installed. Third, evaluation of genetic markers for June sucker to distinguish broodstock from sympatric Utah sucker, Catostomus ardens (U.S. Fish and Wildlife Service 1995). Conservation recommendations: The recovery plan for June sucker includes the following recommendations: (1) minimize habitat factors limiting recruitment in the Provo River and Utah Lake by investigating habitat use by June suckers and optimal habitat management, (2) protect June suckers from introduced predators in Provo River and Utah Lake by investigating effects of introduced predators on June sucker recruitment, and (3) enforce June sucker regulations and protective measures by increasing the presence of government employees at sensitive sites (U.S. Fish and Wildlife Service 1995).

Belk, M.C. 1998. Age and growth of June sucker (Chasmistes liorus) from otoliths. Great Basin Naturalist 58: 390-392. Heckmann, R.A., C.W. Thompson \& D.A. White. 1981. Fishes of Utah Lake. Great Basin Naturalist Memoirs 5: 107-127. Jordan, D.S. 1878. A synopsis of the family Catostomidae. Bull. U.S. Nat. Mus. 12: 97-237.

Miller, R.R. \& G.R. Smith. 1981. Distribution and evolution of Chasmistes (Pisces: Catostomidae) in western North America. Occ. Pap. Mus. Zoo. Univ. Michigan 696: 1-46. Modde, T. \& N. Muirhead. 1994. Spawning chronology and larval emergence of June sucker (Chasmistes liorus). Great Basin Naturalist 54: 366-370.

Scoppetone, G.G. 1988. Growth and longevity of the cui-ui and longevity of other catostomids and cyprinids in Western North America. Trans. Amer. Fish. Soc. 117 : $301-307$. Shirley, D.L. 1983. Spawning ecology and larval development of the June sucker. Proceedings of the Bonneville Chapter of the American Fisheries Society (1983): 18-36.

U.S. Fish and Wildlife Service. 1986. Endangered and threatened wildlife and plants; final rule determining June sucker (Chasmistes liorus) to be an endangered species with critical habitat. Federal Register Volume 51(61): 10851-10857.

U.S. Fish and Wildlife Service. 1995. June sucker (Chasmistes liorus) Recovery Plan. Salt Lake City, Utah. 9 pp. 